\title{
Actual Management of Primary Gastric Lymphoma - An Interdisciplinary Approach
}

\author{
Mircea Manuc ${ }^{1,2}$, Gabriel Becheanu ${ }^{2,3}$, Teodora-Ecaterina Manuc ${ }^{1,2}$, Carmen Preda ${ }^{1,2}$, Monica Lacatus ${ }^{2,4}$ \\ 'Department of Gastroenterology and Hepatology, Fundeni Clinical Institute, Bucharest, Romania \\ 2"Carol Davila" University of Medicine and Pharmacy, Bucharest, Romania \\ " "Victor Babes" National Institute of Pathology, Bucharest \\ ${ }^{4}$ Department of General Surgery, Fundeni Clinical Institute, Bucharest, Romania
}

Corresponding author:

Carmen Preda, MD

Fundeni Clinical Institute,

258 Fundeni Street, Bucharest,

Romania

E-mail: carmenmonica.preda@gmail.com

\section{Rezumat \\ Managementul actual al limfomului gastric primitiv - un abord interdisciplinar}

Limfomul primitiv gastric se numără printre afecțiunile în care rolul chirurgiei ca primă linie de tratament a scăzut considerabil în ultimele decade. Remisiunile obținute prin eradicarea Helicobacter pylori şi răspunsul favorabil la chimio- şi radioterapie au schimbat complet abordarea şi prognosticul acestei boli. Diagnosticul precoce şi stadializarea corectă sunt esențiale pentru tratamentul limfomului gastric. Sunt incluse aici endoscopia digestivă superioară cu biopsii multiple, examenul histopatologic şi imunohistochimic, teste de depistare a infecției cu Helicobacter pyori şi ecoendoscopia pentru evaluarea corectă a extensiei tumorale în peretele gastric şi a afectării ganglionare regionale. Strategia terapeutică este diferită în funcție de stadiul bolii. În prezent, prima linie terapeutică pentru majoritatea formelor localizate de boală este reprezentată de tratamentul de eradicare a infecției cu Helicobacter pylori, obținându-se astfel remisiuni pe termen lung într-un interval de câteva luni. În stadii avansate, la pacienții fără răspuns la terapia de eradicare sau în cazurile Helicobacter pylori negative sunt recomdate chimio- şi radioterapia. Tratamentul chirurgical nu mai este actualmente indicat ca şi primă linie, fiind rezervat complicațiilor precum sângerarea severă sau perforația tumorii în cursul terapiilor conservatoare. Abordul multidisciplinar este, deci, foarte important ca de altfel în toată patologia malignă. În perspectivă sunt aşteptate rezulate încurajatoare de la noi agenți terapeutici, care să permită un tratament individualizat fiecărui pacient în parte. 
Cuvinte cheie: limfom primitiv gastric, Helicobacter pylori, limfom MALT

\begin{abstract}
Primary gastric lymphoma is certainly one of the subjects where the surgeon's role has truly diminished in the last decades. The large number of complete remissions after Helicobacter pylori eradication and the good response to radiotherapy and chemotherapy have completely changed the management and prognosis of this uncommon disease. Early detection and accurate stage workup are essential for gastric lymphoma management. This includes endoscopy with mapping biopsies, histopathology with immunohistochemistry, Helicobacter pylori testing and endoscopic ultrasound for accurate gastric and nodal involvement. First line of treatment is Helicobacter pylori eradication, a positive response of the disease being expected within several months. Chemotherapy and radiotherapy are recommended in advanced stages or in case of non-response to first line treatment. Currently, the surgical approach is uncommon in the initial treatment strategy and is reserved only for acute complications like severe bleeding or perforation. Multidisciplinary management is very important in all malignancies including gastric neoplasia and especially in primary gastric lymphoma. Future perspectives might bring about new therapeutic targets and a personalized approach to every patient diagnosed.
\end{abstract}

Key words: primary gastric lymphoma, Helicobacter pylori, mucosa-associated lymphoid tissue

\section{Introduction}

Most of primary gastric lymphomas are nonHodgkin lymphomas derived either from small B-cells in extra-nodal marginal zone - Mucosa Associated Lymphoid Tissue (MALT) or from diffuse large $\mathrm{B}$ cells in the stomach (DLBCL). These tumors are rare, representing between 3 to $5 \%$ of all gastric malignancies. In the western world, the stomach is the most frequent extra nodal localization of non-Hodgkin lymphomas, representing $66 \%$ of all gastrointestinal tract lymphomas, $30-45 \%$ of all extra nodal lymphomas and around 10\% of all non-Hodgkin lymphomas (1). Gastric $\mathrm{T}$ cell non-Hodgkin lymphoma is a rare entity accounting for $5 \%$ of all gastric lymphomas (2). Gastric Hodgkin lymphoma is even less frequent with only few case-reports in literature (3).

The relationship between Helicobacter pylori (H. Pylori) and primary gastric lymphoma was described in 1991 by Wotherspoon $\mathrm{AC}$ et al, who published that $\mathrm{H}$. Pylori can be isolated in more than $90 \%$ of gastric biopsies (4). However, it took more than a decade to shift strategies and change the current management of the disease.

From as recent as 15 years ago there are articles recommending surgery as the standard treatment for primary gastric lymphomas. For example, in 2003 Bellini et al wrote that in patients with IE-IIE stages of disease chemotherapy should precede surgery while in patients with IIIE-IVE stages, the inverse sequence is more effective in achieving longer survival rates (5). Even with a long-term survival after surgery ranging between $75-95 \%$ (6), the problem with total gastrectomy is mainly related to nutritional complications and low-quality of life in these patients, in spite of a cured disease.

\section{Pathogenesis}

Gastric mucosa has no structured lymphatic tissue, but after an inflammatory process, lymphatic follicles may appear, configuring the so-called mucosa-associated lymphoid tissue (MALT) (7). The pathogenic cascade leading to gastric lymphoma was revealed by 
Genta et al, who correlated MALT onset with H. pylori related gastritis (8). It is important to understand the "lymphogenesis" as a two-step process, the first one being a monoclonal lymphocytic proliferation related to $\mathrm{H}$. pylori gastritis, and the second, the production of immortalized lymphocytes independent from the underlying $\mathrm{H}$. pylori infection. Therapeutic implications are linked to this evolution, since a limited disease will respond to eradication therapy in a much larger percentage compared to an advanced stage disease (9).

Currently, it is well known that almost 90\% of gastric MALT lymphomas are related to H. pylori infection. Although randomized controlled trials were not conducted due to ethical reasons, mucosal healing after $\mathrm{H}$. pylori eradication was accomplished for early stages, therefore Hill's criteria of causality was fulfilled (10). For the remaining $10 \%$ of cases, other pathogens, like $\mathrm{H}$. heilmannii, $\mathrm{H}$. felis, H. bizzozeroni, H. salomonis, H. suis and $H$. bovis, could possibly be involved. There are some patients where no infectious pathogens could be identified (11).

However, the low incidence of gastric lymphoma, especially in areas with high prevalence of $\mathrm{H}$. pylori gastritis, supports the idea that some particular conditions are required for its development. This might be related to bacterial specific characteristics, even though no virulence factor related to different $H$. pylori strains has been proven (12). Another explanation could come from the interaction between bacteria and host specific $\mathrm{T}$ helper cells in presence of genetic characteristics like the presence of HLA-DQA1*0103, HLA-DQB1* 0601 alleles or DQA1*0103-DQB1*0601 haplotypes (13).

Acquired or congenital immunosuppressive conditions are risk factors for lymphoma as well. Up to $23 \%$ of lymphomas arising from the gastrointestinal tract are reported in HIVpositive patients (14).

\section{Pathology}

The diagnosis of primary gastric lymphoma is based on several histological criteria according to WHO and should be confirmed by an experimented pathologist $(15,16)$. The final diagnosis is obtained after a four-step diagnostic procedure, including standard pathology, immunohistochemistry, Helicobacter pylori testing and molecular analysis (optional). Fig. $1 A, B, C$ and Fig. $2 A, B, C$ present a B-cell and T-cell lymphoma in standard coloration and specific immunohistochemistry.

\section{Standard Pathology}

In the earliest stages, neoplastic cells adopt a

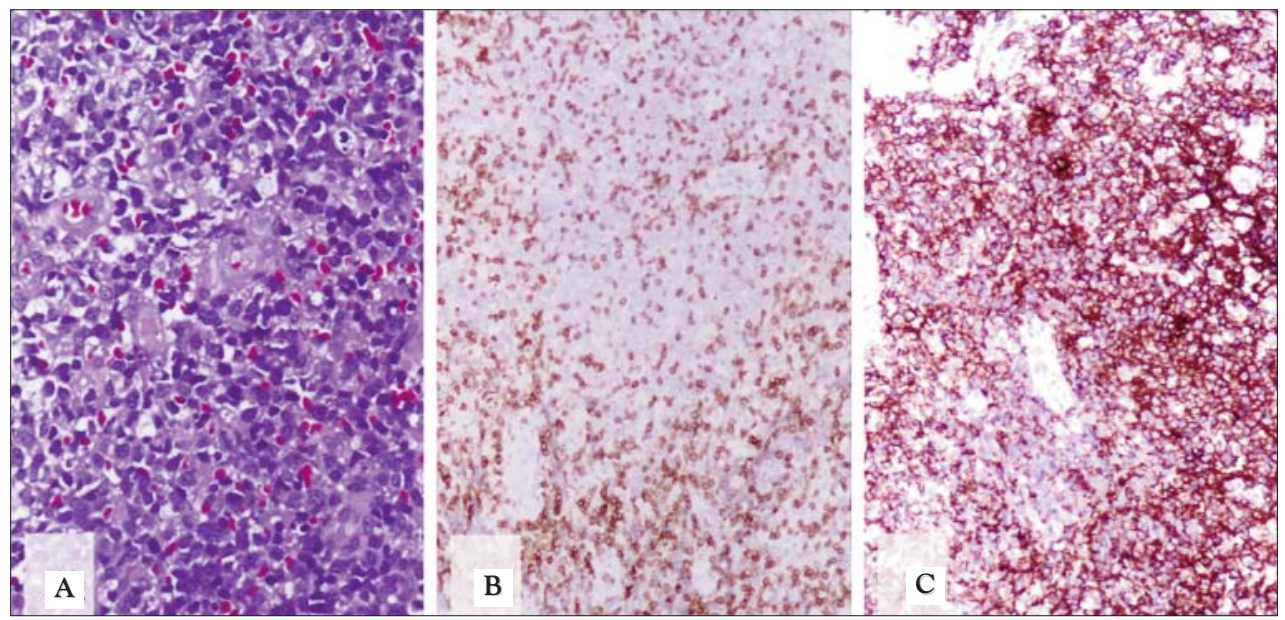

Figure 1. (A) B-cell lymphoma A- H-E staining, 20 fold magnification; (B) CD 3 staining in IHC, 10 fold magnification; (C) CD 20 staining in IHC, 10 fold magnification 


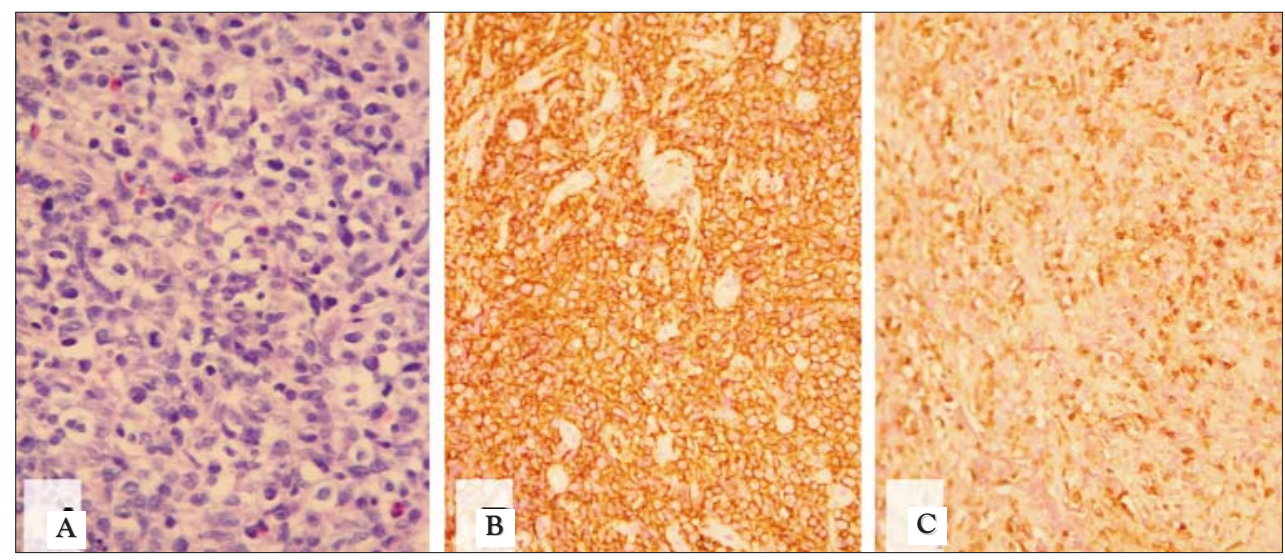

Figure 2. Figure 1-B: T-cell lymphoma A- H-E staining, 20 fold magnification; B- L26 staining in IHC, 10 fold magnification; C- CD 45 staining in IHC, 10 fold magnification

peri-follicular distribution, and in time this infiltrate extends into the lamina propria, moving away from the follicles, damaging the epithelial glands and consequently generating glandular architecture destruction (lymphoepithelial lesion). Lymphoid follicles can be frequently seen and sometimes colonization of the germinal center may occur (17).

Neoplastic cells have variable morphology, including mature round lymphocyte cells resembling germinal center centrocytes with irregular nuclei, cells with monocytoid/ marginal zone B-cell appearance and cells with lymphoplasmacytic appearances. Plasma cell differentiation is a frequent finding, and in some cases may be very prominent. Large neoplastic cells might be isolated, but if abundantly present in important sheets, the diagnosis of an associated diffuse large B-cell lymphoma (DLBCL) should be suspected (16).

\section{Immunohistochemistry}

Immunohistochemistry is used to distinguish MALT lymphoma from other non-Hodgkin lymphomas or from other non-neoplastic infiltrates.

Staining for CD20 or another pan B-cell antigen confirms the B-cell nature of the infiltrate. Staining for CD43 might be helpful in differentiating normal B-cells (which are negative) from neoplastic B-cells proliferation (MALT lymphoma, lymphocytic leukemia, small lymphocytic lymphoma, Mantle cell lymphoma). Staining for CD5 might differentiate MALT lymphomas (usually negative) from chronic lymphocytic leukemia/ small lymphocytic lymphoma, which can also express CD23 or from Mantle cell lymphoma, which coexpresses cyclin D1. A stain for cytokeratin may help to identify lymphoepithelial lesions, and a stain for follicular dendritic cells (eg, antiCD21) will identify indistinct lymphoid follicles. If large B-cells are present, staining for CD10, bcl-2 and bcl- 6 should be used in order to distinguish neoplastic cells from residual germinal centre centroblasts (which are usually negative) (18).

\section{Molecular Analysis}

Molecular analysis is optional for the moment, but it might be useful in order to increase prognosis accuracy and guide the choice of treatment (19).

The most important parameter in the analysis is the translocation $\mathrm{t}(11 ; 18)(\mathrm{q} 21 ; \mathrm{q} 21)$, which is a strong predictor of non-response to H. pylori eradication therapy. It can be found in $25 \%$ of gastric MALT lymphomas, but much more frequently in cases with lack of response to eradication therapy (47-68\%), when com- $^{-}$ pared to only $3 \%$ of gastric MALT lymphomas that respond to $H$. pylori eradication (20). Moreover, t(11;18)(q21;q21) was significantly associated with treatment failure of single oral 
alkylating agents (chlorambucil or cyclophosphamide), but did not predict the response to treatment with the nucleotide analogue cladribine $(2 \mathrm{CdA})$ or the anti-CD20 antibody rituximab (21).

Translocation $\mathrm{t}(11 ; 18)(\mathrm{q} 21 ; \mathrm{q} 21)$ can be detected by FISH technique or by reverse transcription PCR (RTePCR). Both methods can be applied to routine formalin- fixed paraffin-embedded tissue biopsies and showed concordant results. Several other molecular markers might be used, for their prognostic value but they are not used as routine testing for the moment (22).

\section{Helicobacter pylori Testing}

Testing for H. pylori is a compulsory part of the evaluation, and histopathology is the standard testing method (23). It was shown that with at least 5 biopsies, the sensitivity of histology is increased to up to $95 \%$. The biopsies taken distantly from the lesion (antrum, corpus) are stained with $\mathrm{H} \& \mathrm{E}$, Giemsa, alcian blue or cresyl violet (24). Besides H. pylori, histological examination also allows the detection of $\mathrm{H}$. heilmannii, another bacteria related to the development of gastric lymphoma (11).

False negative tests might result in the absence of a 4-week antibiotic free interval, and 2 weeks for PPI (25). In case of a negative result on a routine stain, it has to be followed by immuno-histochemistry with anti-H. pylori antibodies or by the FISH technique (26).

In the future there will be more testing through real-time PCR since it is easy to perform, has a good sensitivity and specificity, and can also evaluate macrolide resistance (27). There is no consensus amongst the current studies; therefore there are no current guidelines for real-time PCR testing.

\section{Clinical Features}

The symptoms can be widely variable and non-specific, ranging from minor dyspeptic complaints (present in more than $78 \%$ of cases), unintentional weight loss $(25 \%)$, to "alarm symptoms" like upper digestive hemorrhage (19\%), anemia or persistent vomiting (18\%). Moreover, systemic symptoms like fever and nocturnal sweats are rarely reported (less than 13\%). Large lesions may be palpable in the epigastrium in advanced cases, and sometimes adenopathies might be observed (28).

\section{Endoscopic Diagnosis}

In case of a suspected gastric lymphoma during endoscopy, a comprehensive evaluation of the whole stomach is mandatory, along with many biopsies (minimum 10) from normal and abnormal mucosa (mapping procedure). In case of pathological suspicion, if the endoscopic procedure and the biopsies were inadequate in regards to this protocol, a second endoscopy has to be performed (29). The same mapping procedure will be done during monitoring, after specific treatment (1).

Endoscopic lesions are unspecific, most of the time suggesting malignancy (vegetant tumors, infiltrated folds of the stomach, malignant ulcer - Fig. $3 A, B$ ), but in several cases mimicking a benign lesion (superficial erosions or ulcerations, thickening or nodularity of the gastric folds, or dispersed petechia - Fig. $3 C, D$ ). In order to improve endoscopic diagnosis, a classification of endoscopic aspects was proposed in 2010 (Table 1), although its utility in daily practice is limited due to the fact that nearly $15 \%$ of lymphomas can be found in normal or benign-appearing gastric mucosa (30).

In the future, the value of new endoscopical techniques like magnification, NBI (Narrow Band Imaging), FICE (Flexible Spectral Imaging Color Enhancement) or I-SCAN are currently under evaluation, but more data are needed prior to using them as diagnostic standards. A tree-like appearance (TLA), with abnormal vascularization and loss of glandular structure on NBI imaging was found to be useful for differentiation from early gastric carcinoma (where blood vessels are curly and variable in size). TLA can also be used for prognosis, since the residual MALT lymphoma after treatment was correlated with the retention of TLA in all cases that had TLA before 

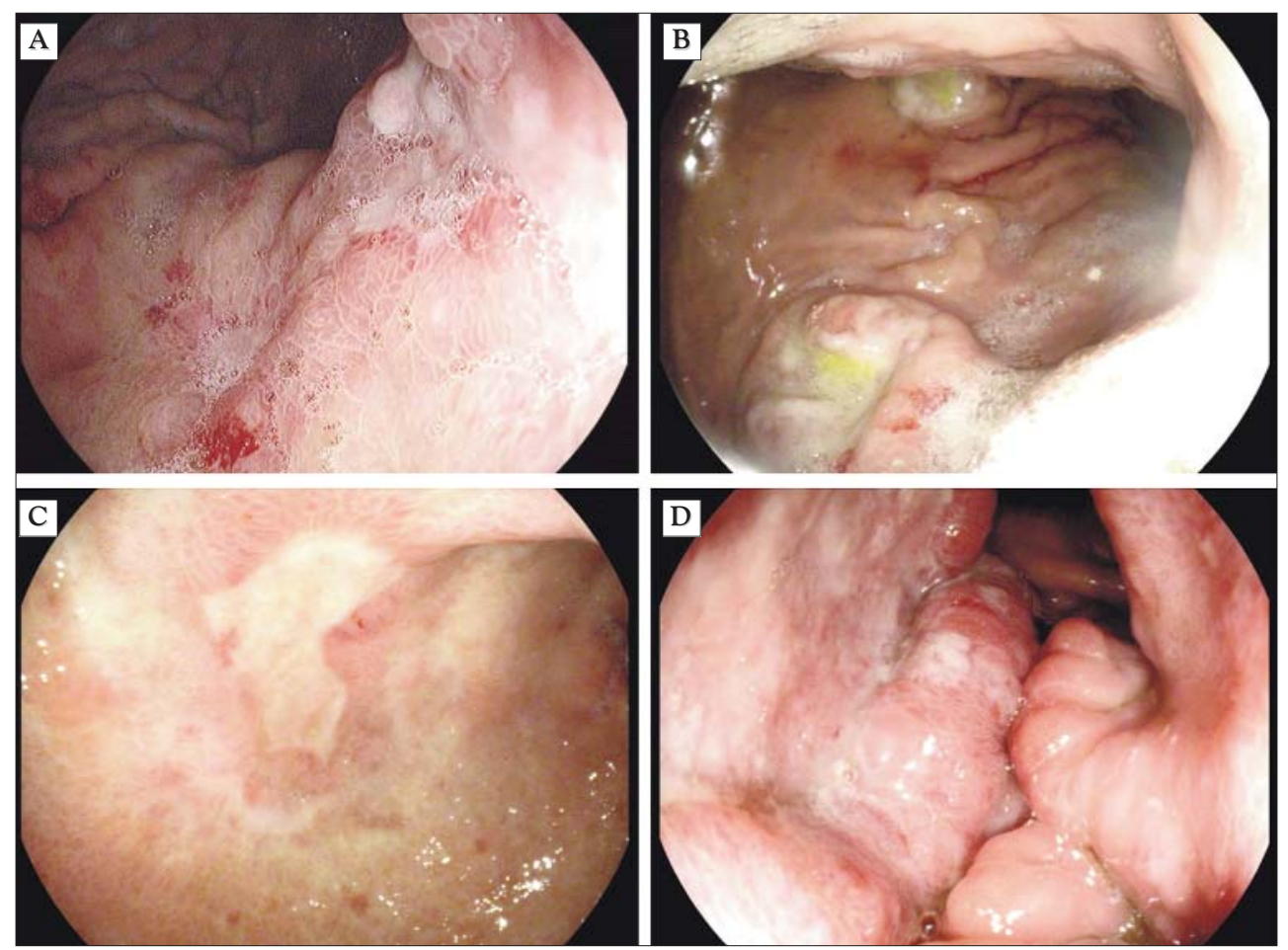

Figure 3. Pictures showing different endoscopic appearances with gastric lymphomas using high definition white light endoscopy

Table 1. Ann Arbor lymphoma staging, modified by Musshoff, for extranodal lymphomas (36)

\begin{tabular}{ll}
\hline Stage of disease & Traits of stage \\
\hline Stage I & Single lymphatic organ or extranodal site \\
\hline Stage II & $\begin{array}{l}\text { Two or more lymphatic regions on the same side of the diaphragm, or a single } \\
\text { extranodal organ plus lymph node involvement on the same side of the diaphragm }\end{array}$ \\
\hline Stage II-1 & Regional lymph nodes involved \\
\hline Stage II-2 & Distant lymph nodes involved \\
\hline Stage III & Lymph node involvement detected on both sides of the diaphragm \\
\hline Stage IV & Disseminated disease with involvement of other extranodal sites (i.e., liver, bone \\
& marrow, abdominal wall) \\
\hline
\end{tabular}

treatment (31). On the other hand, only $75 \%$ of gastric lymphomas showed the TLA profile, and it is not known if there are differences between TLA positive and TLA negative lymphomas.

\section{Pre-treatment Work-up and Staging}

In a patient with a confirmed gastric primary lymphoma, initial evaluation should include a complete physical examination (extensive lymph node palpation) and laboratory tests (routine blood and biochemistry tests, lactate dehydrogenase, beta-2-microglobulines, electrophoresis of plasmatic proteins, viral testing for $\mathrm{HBV}, \mathrm{HCV}$, HIV). Imaging evaluation includes echoendoscopy and thoraco-abdomino-pelvic CT scan. An ileo-colonoscopy can be performed but it is not considered mandatory by all authors (32).

European Society of Medical Oncology (ESMO) recommends bone marrow biopsy in all gastric lymphomas (33). However, recent data challenges the importance of bone marrow biopsy given the facts that initial management and outcome are not modified by marrow involvement. Therefore, bone marrow biopsy should be reserved to DLBCL or in 
MALT lymphomas with inadequate response to $H$. pylori eradication, before initiation of chemotherapy or radiation (34).

If $\mathrm{H}$. pylori is absent on histopathology specimens, a serological test is recommended (23). In case of non-response to $\mathrm{H}$. pylori therapy, cultures can be used in order to test for antimicrobial susceptibility. Urea breath test or fecal antigen is recommended for confirming $\mathrm{H}$. Pylori eradication after therapy. These last 3 methods of testing should be performed after a 4-week antibiotic free interval and at least 2 weeks after PPI withdrawal (25).

FDG-PET is currently recommended only for diffuse large B-cell lymphomas (DLBCL) and follicular lymphomas, in order to determine the chemosensitivity under treatment by immunochemotherapy. Moreover, it is currently under evaluation for MALT - lymphomas unresponsive to $\mathrm{H}$. pylori eradication in order to search for potential transformation into DLBCL (35).

Three important characteristics contribute to an adequate staging: the depth of the invasion into the gastric wall, extragastric nodal involvement, and systemic spread of the disease. There are several staging criteria, and
EGILS recommend the use of both Musshoff modified Ann Arbor and Paris staging systems $(36,37)$. Full classifications are presented in Tables 2 and 3.

Endoscopic ultrasound (EUS) is mandatory for the staging protocol. It is the only investigation that allows a close assessment of depth invasion through the gastric layers and can also be used to evaluate perigastric lymph nodes. EUS can help differentiate between stages like I1E, II1E, respectively T1e4/N0/1. Moreover, EUS findings can be used as a predictive tool for remission after therapy (38).

Overall accuracy for tumor (T) staging (depth of gastric invasion) is $90 \%$, and node involvement (N) staging (perigastric lymph nodes) is $80 \%$. An important factor for EUS technique is the level of expertise in lymphoma staging. Previous data from low-volume centers revealed an accuracy of less than $55 \%$ (39). Therefore, these patients need to be referred to centers with expertise in EUS gastric lymphoma assessment.

Other newer techniques like contrastenhanced Doppler imaging or elastography can be used to increase the staging accuracy, but data were inconclusive and they are not

Table 2. Paris staging system for primary gastrointestinal lymphomas (37)

\begin{tabular}{|c|c|}
\hline Stage of disease & Traits of stage \\
\hline$\overline{T x}$ & Lymphoma extent unspecified \\
\hline TO & No evidence of lymphoma \\
\hline $\mathrm{T} 1 \mathrm{~m}$ & Lymphoma confined to the mucosa \\
\hline $\mathrm{T1} \mathrm{sm}$ & submucosa \\
\hline $\mathrm{T} 2$ & Lymphoma infiltrates muscularis propria or subserosa \\
\hline T3 & Lymphoma penetrates serosa without invading adjacent structures \\
\hline T4 & Lymphoma infiltrates adjacent structures or organs \\
\hline $\mathrm{Nx}$ & Nodal involvement not assessed \\
\hline NO & No evidence of lymph node involvement \\
\hline N1 & $\begin{array}{l}\text { Involvement of regional lymph nodes (for GL: perigastric nodes, as well as those } \\
\text { located along the splenic, the common hepatic and the left gastric arteries }\end{array}$ \\
\hline N2 & Involvement of intra-abdominal lymph nodes beyond the regional area \\
\hline N3 & Involvement of extra-abdominal node \\
\hline $\mathrm{Mx}$ & Dissemination not assessed \\
\hline MO & No evidence of extranodal dissemination \\
\hline M1 & Noncontinuous involvement of separate sites in the Gl tract (i.e., stomach and rectum) \\
\hline $\mathrm{M} 2$ & Noncontinuous involvement of other tissues or organs \\
\hline $\mathrm{Bx}$ & Involvement of bone marrow not assessed \\
\hline $\mathrm{BO}$ & No evidence of bone marrow involvement \\
\hline $\mathrm{B} 1$ & Lymphomatous infiltration of the bone marrow \\
\hline
\end{tabular}


Table 3. Endoscopic classification of lymphoma (30)

\begin{tabular}{ll}
\hline Type & Main endoscopic presentation \\
\hline Ulcerative & Single or multiple ulcerations or multiple erosions \\
\hline Exophytic & Tumor-like appearance with an irregular or polypoid mass \\
\hline Hypertrophic & Large or giant folds; nodular pattern \\
\hline Mixed & A combination of more than one pattern A combination of more than one pattern \\
\hline Petechial haemorrhage & Presence of several mucosal petechial hemorrhages \\
\hline Normal/hyperaemic & Normal appearing mucosa/hyperaemic changes \\
\hline
\end{tabular}

recommended on daily practice (40). The value of EUS-FNA biopsies in perigastric lymph node involvement is highly debated, even when a 19 gauge needle is used, due to the low accuracy in low grade lymphomas (41).

\section{Therapy}

The therapeutic approach considers multiple factors starting from histopathological classification and tumor staging.

\section{Gastric MALT Lymphomas (with small $B$-cells and low grade of malignancy) \\ a. eradication of $H$. pylori}

The majority of cases are localized, therefore the first line therapy is represented by eradication of Helicobacter pylori, recommended in both $\mathrm{H}$ pylori positive and negative patients $(15,33)$. In $\mathrm{H}$. pylori positive patients complete remission rates are around 60 to $80 \%$, while for $\mathrm{H}$. Pylori negative patients, rates reach around $25-46 \%$ of cases $(42,43)$. This suggests that other bacteria which could be eradicated with antibiotic regimen are involved in the pathogenesis of the disease.

According to Maastricht recommendations, a triple or quadruple regimen (even with or without a bismuth component) should be followed for 14 days, taking into account local resistance to clarithromycin and imidazoles (25). Evaluation for eradication is mandatory and has to be done also endoscopically 6 weeks after treatment completion, in order to assess tumoral evolution. If considered, $13-\mathrm{C}$ urea breath test can be performed in order to correctly evaluate the eradication. After eradication of $\mathrm{H}$. pylori, the remission could be achieved between 3-24 months (median 6 months).

The follow-up in remission assessment includes endoscopy with biopsies every 6 months. According to GELA scoring system, there are 4 histological possibilities which guide follow-up and subsequent treatment. GELA histological grading system for posttreatment evaluation of gastric MALT lymphoma is presented in Table 4 (44).

Complete remission is achieved if 2 consecu- $^{-}$

Table 4. GELA histological grading system for post-treatment evaluation of gastric MALT lymphoma (44)

\begin{tabular}{llll}
\hline Score & Lymphoid infiltrat & LEL & Stromal changes \\
\hline CR (complete histological remission) & $\begin{array}{l}\text { Absent or scattered plasma cells and small lymphoid } \\
\text { cells in the LP }\end{array}$ & Absent & $\begin{array}{l}\text { Normal or empty LP } \\
\text { and/orfibrosis }\end{array}$ \\
pMRD (probable minimal residual & $\begin{array}{l}\text { Aggregates of lymphoid cells or lymphoid nodules in } \\
\text { the LP/MM }\end{array}$ & Absent & $\begin{array}{l}\text { Empty LP and/or } \\
\text { fibrosis }\end{array}$ \\
rRD (responding residual disease) & $\begin{array}{l}\text { Dense, diffuse, or nodular extending around glands in } \\
\text { the LP }\end{array}$ & $\begin{array}{l}\text { Focal LEL } \\
\text { or absent }\end{array}$ & $\begin{array}{l}\text { Focal empty LP and/or } \\
\text { fibrosis }\end{array}$ \\
NC (no change) & Dense, diffuse, or nodular & $\begin{array}{l}\text { Present, "may } \\
\text { be absent" }\end{array}$ & No changes \\
\hline
\end{tabular}

MM: muscularis mucosa; LP: Iamina propria; SM: submucosa; LEL: Iymphoepithelial lesions 
Table 4. GELA histological grading system for post-treatment evaluation of gastric MALT lymphoma

\begin{tabular}{llll}
\hline Score & Lymphoid infiltrat & LEL & Stromal changes \\
\hline CR (complete histological remission) & $\begin{array}{l}\text { Absent or scattered plasma cells and small lymphoid } \\
\text { cells in the LP }\end{array}$ & Absent & $\begin{array}{l}\text { Normal or empty LP } \\
\text { and/orfibrosis }\end{array}$ \\
\hdashline pMRD (probable minimal residual & $\begin{array}{l}\text { Aggregates of lymphoid cells or lymphoid nodules in } \\
\text { the LP/MM }\end{array}$ & Absent & $\begin{array}{l}\text { Empty LP and/or } \\
\text { fibrosis }\end{array}$ \\
rRD (responding residual disease) & $\begin{array}{l}\text { Dense, diffuse, or nodular extending around glands in } \\
\text { the LP }\end{array}$ & $\begin{array}{l}\text { Focal LEL } \\
\text { or absent }\end{array}$ & $\begin{array}{l}\text { Focal empty LP and/or } \\
\text { fibrosis }\end{array}$ \\
NC (no change) & Dense, diffuse, or nodular & $\begin{array}{l}\text { Present, "may } \\
\text { be absent" }\end{array}$ & No changes \\
\hline
\end{tabular}

MM: muscularis mucosa; LP: lamina propria; SM: submucosa; LEL: Iymphoepithelial lesions

tive evaluations reveal endoscopic remission of lesions together with histologic remission (CR or pMRD). Partial remission is defined as regression of endoscopic lesions with histological $r R D$, stable disease is defined as the absence of regression of macroscopic lesions and/or RC and progressive disease means more advanced lesions on endoscopy, extragastric dissemination or the evolution to DLBCL. After achieving complete remission, the recurrence is rare and usually appears within the first 2 years, as well as the dissemination or transformation to DLBCL.

Negative predictive factors for lymphoma remission after $\mathrm{H}$. pylori eradication treatment includes advanced stage disease (45), deeper invasion of lymphoma into gastric wall (46), presence of the $\mathrm{t}(11 ; 18)$ API2-MALT1 translocation (20), proximal location of lymphoma in stomach (47) and the initial H. pylori negative status (48). If $\mathrm{H}$. pylori eradication was not achieved, a quadruple-based regimen is recommended as re-treatment of the infection.

\section{b. other therapies}

Second-line therapies like radiotherapy or chemotherapy are recommended in case of non-regression/relapse after eradication of H. pylori or in $t(11: 18)$ translocation (rare occurrence) where non-responsiveness to $\mathrm{H}$. pylori therapy is expected.

Radiotherapy - could be recommended based on the radiosensitivity of small B-cells. For localized lymphoma, low-dose radiotherapy as single therapy generate an excellent response with a complete remission in up to
$96 \%$ of cases without significant side-effects (49), although there are no randomized trials comparing radiotherapy with systemic chemotherapy. Conformational radiotherapy with 30 Gy fractionated in 1,8-2 Gy/session, 5 sessions /week is recommended by GELD/FFCD study group resulting in an overall survival rate of $94 \%$ at 4.9 years (50).

Chemotherapy and immunotherapy should be recommended especially for extra-nodal disseminated gastric lymphomas, and for localized disease with failure to radiotherapy. For the moment there are no strong evidences related to which could be the most effective regimen. As first line therapy, the association of chlorambucil and rituximab was shown to be superior to the monotherapy, with a response rate of $80 \%$ and a PFS survival of $72 \%$ at 5 years (21). In second line, chemotherapies with anthracyclines might be used, but usually these types of therapies have to be reserved for cases with aggressive lymphomas (1).

The presence of perigastric lymph node involvement is reported to be a negative predictive factor of response to $\mathrm{H}$ pylori treatment and alkylating agents 51, but whether $\mathrm{t}$ (11:18) translocation influence response to chemotherapy is still controversial (52).

Regarding the overall response to radiotherapy and chemotherapy, it is important to review the data from (SEER)-Medicare database of gastric MALT, although $\mathrm{H}$. pylori status is not reported. Among 1134 patients, $21 \%$ underwent radiation therapy and 24\% underwent chemotherapy as initial treatment. The median overall survival duration was 6.7 
years. In the subset analysis of stage IE patients, lymphoma-related death occurred more often in the chemotherapy group than in the radiation therapy group (5-year cumulative incidence, $19 \%$ vs $5 \%$ ), and rituximab was associated with a lower death-risk in the subgroup with chemotherapy (53).

\section{Diffuse Large B-Cell Lymphomas (DLBCL)}

Gastric DLBCL is no different than nodal DLBCL, therefore it can be managed similarly (52). First line therapy is chemotherapy and usually a R-CHOP regimen (rituximab + doxorubicin, cyclophosphamide, vincristine, prednisone), recommended for 6-8 cycles at 3 weeks intervals (54). Chemotherapy was showed to be superior to other alternatives like radiotherapy, surgery, even if used in combinations (55). Radiotherapy can be used in addition to the first line chemotherapy, showing a better local response, although not a better long-term survival (56).

Based on general treatment conception for diffuse large B-cell lymphomas, in advanced stage IV, autologous stem-cells transplantation might be an option, particularly in cases with no response to chemotherapy (57). Eradication of $\mathrm{H}$. pylori is also recommended in order to avoid proliferation of small B-cells MALT type.

\section{Surgery}

The surgical approach to gastric lymphoma changed dramatically over the last decade due to complete response rate and long term survival obtained by the combination of chemotherapy with monoclonal antibody (58).

Gastric lymphoma was traditionally referred to surgery for diagnosis, staging and curative reasons (59-61). Most of the studies published reported high rate of disease relapses after surgery which led to the introduction of adjuvant chemotherapy (62). In the early 1990s came the first reports of using chemotherapy as single therapy modality with a 5 year overall survival of $76 \%$ compared with $75 \%$ for the patients treated by surgical curative resection (63).
The surgical approach has a mortality estimated at 8\% (4) and significant morbidity associated with the gastrectomy like malabsorption syndromes, weight loss and dumping syndrome $(64,65)$. The surgical complications overcome the benefits expected from local tumor control. Furthermore, in a study published by Salles et al., surgical resection for localized gastric lymphoma as first step in therapy protocol did not affect survival rate, disease-free survival or complete response rate (66).

The diagnosis and staging role of the surgery became irrelevant nowadays due to increased efficacy of endoscopic biopsy and sensitivity of endoscopic ultrasound, CT scan, gallium scanning and MRI in the evaluation of extra-gastric spread (67-69).

All data suggest that surgery is no longer in the front line of treatment of gastric lymphoma and should be considering only after a nonsurgical treatment and in the cases of disease complications like perforation, obstruction or hemorrhage or unique cases of locally persistent disease.

\section{Surveillance}

In case of low-grade malignancy, the recommended check-up includes - clinical control; systematic blood panel - including LDH, beta2microglobulin, renal and hepatic tests; endoscopic examination with multiple biopsies and depending on cellular type a thoracoabdominal CT-scan. The check-up has to be done at least on an annual basis, for at least 10 years. We have to consider, at least in patients with atrophic gastric and/or intestinal metaplasia also the subsequent 6 -fold increased risk of developing gastric adenocarcinoma (70).

Surprisingly enough, echoendoscopy is not useful for remission evaluation since an echopoor infiltration of the gastric wall may persist for more than 6 months after histological remission and on the other hand, a quasi-normal echo gastric wall may be visible despite histological non-responsiveness (71). In case of highgrade malignancy, the check-up is similar, but it has to be done in the first 2 years bi-annually 
and after that annually. Endoscopy is routine, but CT or PET-CT are currently not recommended, because of no clear benefits (1).

In gastric MALT lymphomas, a true relapse is exceptional and usually corresponds to an incomplete regression of lymphoma, sometimes related to the persistence of $\mathrm{H}$. pylori infection. When $\mathrm{H}$. pylori is still present, it imposes retreatment with a different, quadruple therapy. If the absence of bacteria is confirmed, radiotherapy for localized and chemotherapy for advanced stages must be undertaken (48).

\section{Conclusion}

Primary gastric lymphoma is an entity scarcely encountered in surgical scenarios lately. It's "vanishing act" is mainly related to the exceptional response to $\mathrm{H}$. Pylori eradication and other medical strategies including chemo and radiotherapy. $H$. pylori infection might generate in some predisposed patients gastric lymphoma, probably via strain-host-organ specific interaction. Accurate evaluation of local and systemic extension is important in guiding current management. Ongoing and future research might provide new lines of surgery free treatment and quite possibly even chemotherapy free.

Take home messages:

- The management of gastric lymphomas rely on a multidisciplinary approach (gastroenterologist, radiologist, pathologist, hematologist, oncologist, surgeon) in "referral centers" with expertise;

- An optimal management should have an adequate staging, detection of $\mathrm{H}$. pylori infection, pathological tumoral profile and $\mathrm{t}(11 ; 18)(\mathrm{q} 21 ; \mathrm{q} 21)$ translocation;

- Primary gastric lymphomas are nowadays very much curable by conservative measures, starting with $\mathrm{H}$. Pylori eradication, and followed if necessary, by chemo and/or radiotherapy;

- The need for surgery is guided by tumor complications requiring emergency intervention.

\section{Conflict of Interest}

The authors declare no conflicts of interests.

\section{Author's Contributions}

Manuc Mircea: general concept, endoscopy echoendoscopy; Preda Carmen: treatment; Manuc Teodora Ecaterina: pathogeny, diagnosis; Becheanu Gabriel - pathology; Lacatus Monica: surgery.

\section{References}

1. Matysiak-Budnik T, Fabiani B, Hennequin C, Thieblemont C, Malamut G, Cadiot G, et al. Gastrointestinal lymphomas: French Intergroup clinical practice recommendations for diagnosis, treatment and follow-up (SNFGE, FFCD, GERCOR, UNICANCER, SFCD, SFED, SFRO, SFH). Dig Liver Dis. 2018;50(2):124-131.

2. Chen Y, Chen Y, Chen S, Wu L, Xu L, Lian G, et al. Primary gastrointestinal lymphoma: a retrospective multicenter clinical study of 415 cases in chinese province of guangdong and a systematic review containing 5075 chinese patients. Medicine (Baltimore). 2015;94(47):e2119.

3. Sethi S, Higgins JP, Arber DA, Visser B, Banerjee S. Primary gastric Hodgkin's lymphoma: an extremely rare entity and A diagnostic challenge. Dig Dis Sci. 2015;60(10):2923-2926.

4. Wotherspoon AC, Ortiz-Hidalgo C, Falzon MR, Isaacson PG. Helicobacter pylori-associated gastritis and primary B-cell gastric Iymphoma. Lancet. 1991;338(8776):1175-6.

5. Bellini M, Salvatore G, Di Palma R, Cataneo M, Pede A, De Martino C. Gastric non-Hodgkin Iymphoma: guidelines for the therapeutic approach. Chir Ital. 2003;55(3):391-7. Italian

6. Fischbach W, Schramm S, Goebeler E. Outcome and Quality of Life Favour a Conservative Treatment of Patients with Primary Gastric Lymphoma. Z Gastroenterol. 2011;49(04):430-435.

7. Nagai S, Mimuro H, Yamada T, Baba Y, Moro K, Nochi T, et al. Role of Peyer's patches in the induction of Helicobacter pylori-induced gastritis. Proc Natl Acad Sci U S A. 2007;104(21):8971-6.

8. Genta RM, Graham DY. Primary Gastric MALT lymphoma: trivial condition or serious disease? Helicobacter. 1997;2(s1):56-60.

9. Bertoni F, Coiffier B, Salles G, Stathis A, Traverse-Glehen A, Thieblemont $C$, et al. MALT lymphomas: pathogenesis can drive treatment. Oncology (Williston Park). 2011;25(12): 1134-42, 1147.

10. Guo $Q$, Guo S, Zhang Y. Treatment of gastric MALT Iymphoma with a focus on Helicobacter pylori eradication. Int J Hematol. 2013; 97(6):735-742

11. Park JB, Koo JS. Helicobacter pylori infection in gastric mucosaassociated lymphoid tissue lymphoma. World J Gastroenterol. 2014;20(11):2751-2759.

12. Floch $P$, Mégraud F, Lehours P. Helicobacter pylori Strains and Gastric MALT Lymphoma. Toxins (Basel). 2017;9(4)

13. Kawahara Y, Mizuno M, Yoshino T, Yokota K, Oguma K, Okada H, et al. HLA-DQA1*0103-DQB1*0601 haplotype and Helicobacter pylori-positive gastric mucosa-associated lymphoid tissue Iymphoma. Clin Gastroenterol Hepatol. 2005;3(9):865-8.

14. Schulz C, Schütte $K$, Malfertheiner P. Rare Neoplasia of the Stomach. Gastrointest tumors. 2015;2(2):52-60.

15. Ruskoné-Fourmestraux A, Fischbach W, Aleman BM, Boot H, Du $M Q$, Megraud F, et al. EGILS consensus report. Gastric extranodal marginal zone B-cell lymphoma of MALT. Gut. 2011;60(6):747-58.

16. Stolte M, Bayerdörffer E, Morgner A, Alpen B, Wündisch T, Thiede 
C, Neubauer A. Helicobacter and gastric MALT Iymphoma. Gut. 2002;50 Suppl 3:III19-24.

17. Doglioni C, Ponzoni M, Ferreri AJM, Savio A. Gastric lymphoma: The histology report. Dig Liver Dis. 2011;43:310-18.

18. Bacon CM, Du M-Q, Dogan A. Mucosa-associated lymphoid tissue (MALT) lymphoma: a practical guide for pathologists. J Clin Pathol. 2007;60(4):361-72.

19. Calin GA. Limfomul gastric primitiv. Editura Med Mun; 2002.

20. Liu H, Ye H, Ruskone-Fourmestraux A, De Jong D, Pileri S, Thiede C, et al. T $(11 ; 18)$ is a marker for all stage gastric MALT lymphomas that will not respond to $\mathrm{H}$. pylori eradication. Gastroenterology. 2002;122(5):1286-94

21. Lévy M, Copie-Bergman C, Molinier-Frenkel V, Riou A, Haioun C, Gaulard $P$, et al. Treatment of $\mathrm{t}(11 ; 18)$-positive gastric mucosaassociated lymphoid tissue lymphoma with rituximab and chlorambucil: clinical, histological, and molecular follow-up. Leuk Lymphoma. 2010;51(2):284-90.

22. Alevizos L, Gomatos IP, Smparounis S, Konstadoulakis MM, ZografoS G. Review of the molecular profile and modern prognostic markers for gastric lymphoma: how do they affect clinical practice? Can J Surg. 2012;55(2):117-124.

23. Lehours $P$, Ruskone-Fourmestraux $A$, Lavergne $A$, Cantet $F$, Megraud F, Groupe d'Etude des Lymphomes Digestifs (GELD) for the Fédération Française de Cancérologie Digestive (FFCD). Which test to use to detect Helicobacter pylori infection in patients with low-grade gastric mucosa-associated lymphoid tissue lymphoma? Am J Gastroenterol. 2003;98(2):291-295.

24. Hartman DJ, Owens SR. Are Routine Ancillary Stains Required to Diagnose Helicobacter Infection in Gastric Biopsy Specimens? Am J Clin Pathol. 2012;137(2):255-260.

25. Malfertheiner P, Megraud F, O'Morain CA, Gisbert JP, Kuipers EJ, Axon AT, et al. Management of Helicobacter pylori infection - the Maastricht V/Florence Consensus Report. Gut. 2017;66(1):6-30.

26. Russmann H, Kempf VAJ, Koletzko S, Heesemann J, Autenrieth IB. Comparison of Fluorescent In Situ Hybridization and Conventional Culturing for Detection of Helicobacter pylori in Gastric Biopsy Specimens. J Clin Microbiol. 2001;39(1):304-308.

27. Bilgilier C, Simonitsch-Klupp I, Kiesewetter B, Raderer M, Dolak W, Makristathis $A$, et al. Prevalence of clarithromycin-resistant Helicobacter pylori strains in gastric mucosa-associated lymphoid tissue lymphoma patients. Ann Hematol. 2016; 95(7):1115-20.

28. Cui X, Zhou T, Jiang D, Liu H, Wang J, Yuan S, et al. Clinical manifestations and endoscopic presentations of gastric lymphoma: a multicenter seven year retrospective survey. Rev Esp Enferm Dig. 2017;109(8):566-571.

29. Xu W, Zhou C, Zhang G, Wang H, Wang L, Guo J. Repeating gastric biopsy for accuracy of gastric lymphoma diagnosis. Gastroenterol Nurs. 2010;33(4):313-7.

30. Zullo A, Hassan C, Cristofari F, Perri F, Morini S. Gastric low-grade mucosal-associated lymphoid tissue-lymphoma: Helicobacter pylori and beyond. World J Gastrointest Oncol. 2010;2(4):181-6.

31. Chiu PW, Wong TC, Teoh AY, To KF, Liu SY, Wong SK, et al. Recognition of changes in microvascular and microstructural patterns upon magnifying endoscopy predicted the presence of extranodal gastric MALToma. J Interv Gastroenterol. 2012;2(1):3-7. Epub 2012 Jan 1.

32. Fischbach W. Gastric mucosa-associated lymphoid tissue lymphoma: a challenge for endoscopy. Gastrointest Endosc. 2008:68(4):632-634.

33. Zucca E, Copie-Bergman C, Ricardi U, Thieblemont C, Raderer M, Ladetto M, et al. Gastric marginal zone lymphoma of MALT type: ESMO Clinical Practice Guidelines for diagnosis, treatment and follow-up. Ann Oncol. 2013;24 Suppl 6:vi144-8.

34. Choi SI, Kook MC, Hwang S, Kim YI, Lee JY, Kim CG, et al. Prevalence and implications of bone marrow involvement in patients with gastric mucosa-associated lymphoid tissue lymphoma. Gut Liver. 2018; 12(3):278-287.

35. Davis BS, Thompson TA, Wolin EA. 18F-FDG PET/CT Imaging of Primary Gastric Lymphoma. J Nucl Med Technol. 2016;44(4): 263-264.

36. Musshoff K, Schmidt-Vollmer H. Proceedings: Prognosis of nonHodgkin's lymphomas with special emphasis on the staging classification. Z Krebsforsch Klin Onkol Cancer Res Clin Oncol. 1975;83(4):323-341.

37. Ruskoné-Fourmestraux A, Dragosics B, Morgner A, Wotherspoon $A$, De Jong D. Paris staging system for primary gastrointestinal lymphomas. Gut. 2003;52(6):912-913.

38. Sackmann M, Morgner A, Rudolph B, Neubauer A, Thiede C, Schulz $\mathrm{H}$, et al. Regression of gastric MALT lymphoma after eradication of Helicobacter pylori is predicted by endosonographic staging. MALT Lymphoma Study Group. Gastroenterology. 1997;113(4):1087-90.

39. Fischbach W, Goebeler-Kolve M-E, Greiner A. Diagnostic accuracy of EUS in the local staging of primary gastric lymphoma: Results of a prospective, multicenter study comparing EUS with histopathologic stage. Gastrointest Endosc. 2002:56(5):696-700.

40. Schizas D, Ntanasis-Stathopoulos I, Tsilimigras DI, Sioulas AD, Moris D, Spartalis E, et al. The role of endoscopic ultrasound in the diagnosis and management of primary gastric lymphoma. Gastroenterol Res Pract. 2017:2017:2397430. Epub 2017 Mar 16.

41. Ribeiro A, Pereira D, Escalón MP, Goodman M, Byrne GE. EUSguided biopsy for the diagnosis and classification of lymphoma. Gastrointest Endosc. 2010;71(4):851-855.

42. Raderer M, Wöhrer S, Kiesewetter B, Dolak W, Lagler H, Wotherspoon A, et al. Antibiotic treatment as sole management of Helicobacter pylori-negative gastric MALT Iymphoma: a single center experience with prolonged follow-up. Ann Hematol. 2015; 94(6):969-73.

43. Choi YJ, Kim N, Paik JH, Kim JM, Lee SH, Park YS,et al. Characteristics of Helicobacter pylori- positive and Helicobacter pylori -negative gastric mucosa-associated lymphoid tissue lymphoma and their influence on clinical outcome. Helicobacter. 2013;18(3):197-205.

44. Copie-Bergman C, Wotherspoon AC, Capella C, Motta T, Pedrinis E, Pileri SA, et al. Gela histological scoring system for post-treatment biopsies of patients with gastric MALT Iymphoma is feasible and reliable in routine practice. Br J Haematol. 2013;160(1):47-52.

45. Ruskoné-Fourmestraux A, Lavergne A, Aegerter PH, Megraud F, Palazzo L, de Mascarel A, et al. Predictive factors for regression of gastric MALT Iymphoma after anti-Helicobacter pylori treatment. Gut. 2001;48(3):297-303.

46. Chen LT, Lin JT, Tai JJ, Chen GH, Yeh HZ, Yang SS, et al. Long-term results of anti-Helicobacter pylori therapy in early-stage gastric high-grade transformed MALT Iymphoma. J Natl Cancer Inst. 2005;97(18):1345-1353.

47. Kim JS, Chung SJ, Choi YS, Cheon JH, Kim CW, Kim SG, et al. Helicobacter pylori eradication for low-grade gastric mucosaassociated lymphoid tissue lymphoma is more successful in inducing remission in distal compared to proximal disease. $\mathrm{Br} \mathrm{J}$ Cancer. 2007;96(9):1324-8.

48. Kim JS, Kang SH, Moon HS, Sung JK, Jeong HY. Clinical Outcome of Eradication Therapy for Gastric Mucosa-Associated Lymphoid Tissue Lymphoma according to $\mathrm{H}$. pylori Infection Status. Gastroenterol Res Pract. 2016;2016:6794848.

49. Zullo A, Hassan C, Andriani A, et al. Treatment of low-grade gastric MALT-Iymphoma unresponsive to Helicobacter pylori therapy. Med Oncol. 2010;27(2):291-295.

50. Ruskoné-Fourmestraux A, Matysiak-Budnik T, Fabiani B, Cervera P, Brixi $\mathrm{H}$, Le Malicot $\mathrm{K}$, et al. Exclusive moderate-dose radiotherapy in gastric marginal zone B-cell MALT lymphoma: Results of a prospective study with a long term follow-up. Radiother Oncol. 2015;117(1):178-82.

51. Levy M, Copie-Bergman C, Traulle C, Lavergne-Slove A, Brousse $\mathrm{N}$, Flejou JF, et al. Conservative treatment of primary gastric lowgrade B-cell lymphoma of mucosa-associated lymphoid tissue: predictive factors of response and outcome. Am J Gastroenterol. 
2002;97(2): 292-7.

52. Ikoma N, Badgwell BD, Mansfield PF. Multimodality Treatment of Gastric Lymphoma. Surg Clin North Am. 2017;97(2):405-420.

53. Olszewski AJ, Castillo JJ. Comparative outcomes of oncologic therapy in gastric extranodal marginal zone (MALT) Iymphoma: analysis of the SEER-Medicare database. Ann Oncol. 2013;24(5):1352-9.

54. Raderer M, Paul de Boer J. Role of chemotherapy in gastric MALT Iymphoma, diffuse large B-cell lymphoma and other lymphomas. Best Pract Res Clin Gastroenterol. 2010;24(1):19-26.

55. Avilés A, Nambo MJ, Neri N, Huerta-Guzmán J, Cuadra I, Alvarado I, et al. The role of surgery in primary gastric lymphoma: results of a controlled clinical trial. Ann Surg. 2004;240(1):44-50.

56. Martinelli G, Gigli F, Calabrese L, Ferrucci PF, Zucca E, Crosta C, et al. Early stage gastric diffuse large B-cell lymphomas: results of a randomized trial comparing chemotherapy alone versus chemotherapy + involved field radiotherapy. (IELSG 4). [corrected]. Leuk Lymphoma. 2009;50(6):925-31.

57. Armitage J0. My treatment approach to patients with diffuse large B-cell lymphoma. Mayo Clin Proc. 2012;87(2):161-171.

58. Tanaka T, Shimada K, Yamamoto K, Hirooka Y, Niwa Y, Sugiura I, et al. Retrospective analysis of primary gastric diffuse large B cell lymphoma in the rituximab era: a multicenter study of 95 patients in Japan. Ann Hematol. 2012;91(3):383-90.

59. Vasilescu C. Limfomul gastric primitiv. Bucharest: Editura Med Mun; 2002.

60. Vasilescu C, Popa M, Tudor S, Manuc M, Diculescu M. Robotic surgery of locally advanced gastric cancer -- an initial experience. Acta Chir Belg. 112(3):209-212.

61. Procopiuc L, Tudor S, Manuc M, Diculescu M, Vasilescu C. Open vs robotic radical gastrectomy for locally advanced gastric cancer. Int J Med Robot Comput Assist Surg. 2016;12(3):502-508.

62. Shiu MH, Nisce LZ, Pinna A, Straus DJ, Tome M, Filippa DA, et al.
Recent results of multimodal therapy of gastric lymphoma. Cancer. 1986:58(7):1389-99.

63. Maor MH, Velasquez WS, Fuller LM, Silvermintz KB. Stomach conservation in stages IE and IIE gastric non-Hodgkin's lymphoma. $\mathrm{J}$ Clin Oncol. 1990;8(2):266-271.

64. Avilés A, Díaz-Maqueo JC, de la Torre A, Rodriguez L, Guzmán R, Talavera $A$, et al. Is surgery necessary in the treatment of primary gastric non-Hodgkin lymphoma? Leuk Lymphoma. 1991;5(5-6): 365-9.

65. Rackner VL, Thirlby RC, Ryan JA. Role of surgery in multimodality therapy for gastrointestinal lymphoma. Am J Surg. 1991;161(5): 570-575.

66. Salles G, Herbrecht R, Tilly H, Berger F, Brousse N, Gisselbrecht C, et al. Aggressive primary gastrointestinal lymphomas: review of 91 patients treated with the LNH-84 regimen. A study of the Groupe d'Etude des Lymphomes Agressifs. Am J Med. 1991;90(1):77-84.

67. Taal BG, Burgers JM, van Heerde P, Hart AA, Somers R. The clinical spectrum and treatment of primary non-Hodgkin's lymphoma of the stomach. Ann Oncol Off J Eur Soc Med Oncol. 1993;4(10):839-846

68. Rossi A, Rohatiner AZ, Lister TA. Primary gastrointestinal nonHodgkin lymphoma: still an unresolved question? Ann Oncol Off J Eur Soc Med Oncol. 1993;4(10):802-803.

69. Crump M, Gospodarowicz M, Shepherd FA. Lymphoma of the gastrointestinal tract. Semin Oncol. 1999;26(3):324-337.

70. Inaba K, Kushima R, Murakami N, Kuroda Y, Harada K, Kitaguchi M, et al. Increased risk of gastric adenocarcinoma after treatment of primary gastric diffuse large B-cell lymphoma. BMC Cancer. 2013 Oct 26;13:499.

71. Di Raimondo F, Caruso L, Bonanno G, Naso P, Chiarenza A, Fiumara $P$, et al. Is endoscopic ultrasound clinically useful for follow-up of gastric lymphoma? Ann Oncol. 2006;18(2):351-356. 